\title{
Nutrition Politics in the Quinoa Boom: Connecting Consumer and Producer Nutrition in the Commercialization of Traditional Foods
}

\author{
Emma McDonell*
}

Department of Anthropology, Food Studies Institute, Indiana University, USA

"Corresponding author: Emma McDonell, Department of Anthropology, Food Studies Institute, Indiana University, USA, E-mail: ekmcdone@indiana.edu

\begin{abstract}
In the past decade, quinoa (Chenopodium quinoa Willd) has transformed from a local "Indian food," produced and consumed almost exclusively in the Andean highlands, into a global consumer "super food" lauded for its amino acid, vitamin, and mineral content. While popular press articles have criticized quinoa commercialization for provoking a price surge that left small farmers unable to afford eating this nutritious staple, this paper critically examines evidence supporting this argument and investigates the complex and contradictory nutritional politics of the quinoa boom. Drawing on ethnographic fieldwork in the Peruvian high lands, this paper argues that quinoa consumption simultaneously symbolizes a "traditional" past while heralding an economically prosperous future for farmers and the nation of Peru. It demonstrates that changing relations to quinoa consumption are the result of complex individual and family-level negotiations about ideas of bodily health, tradition, and modernity. The article uses the quinoa boom as a case study to point to broader trends and challenges with commercializing traditional nutritional staples. Given the surging demand for super foods, novel foods with exceptional nutritional profiles that are often linked to traditional peoples, this research is prescient and should inform future efforts seeking to leverage demand for super foods for rural development.
\end{abstract}

Received Date: November 10, 2016

Accepted Date: December 23, 2016

Published Date: January 10, 2017

Citation: McDonell, E. Nutrition Politics in the Quinoa Boom: Connecting Consumer and Producer Nutrition in the Commercialization of Traditional Foods. (2016) Int J Food Nutr Sci 4(1): 1- 7.

\section{DOI: $10.15436 / 2377-0619.16 .1212$}

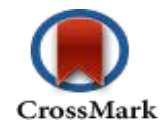

\section{Introduction}

In the past decade, quinoa (Chenopodium quinoa Willd) has transformed from a local "Indian food," produced and consumed almost exclusively in the Andean highlands, into a global consumer "super food." After rapidly gaining acclaim amongst health-conscious first-world consumers for its exceptional nutritional profile, high-end supermarket shelves across the North America, Europe, and Asia are now lined with a rapidly expanding array of products featuring the "lost crop of the Inca" while menus of some of the world's most exclusive restaurants now feature quinoa salads, entrees, and pastries. In Peru, the world's leading quinoa producer, exports increased twelve-fold and prices quadrupled between 2009 and $2013^{[1]}$ (Figure 1). With prices spiking due to the demand surge, thousands of highland subsistence agriculturalists took up market-oriented quinoa production and quinoa commercialization became a model for multicultural development's project to refashion indigenous identity for "modernity." The Peruvian state, along with local and international NGOs and development organizations, framed the quinoa boom as the long-awaited opportunity to transform highland subsistence farmers, long lamented as "culturally backward" and "economically unproductive, into "modern" capital-accruing producers ${ }^{1}$ that would contribute to the nation's export-focused development model.

This paper uses the quinoa boom as a case study to examine the politics of nutrition in "traditional" food commercialization, foregrounding how health food trends amongst firstworld consumers, and specifically desires for traditional foods,

${ }^{1}$ wish to note that transforming subsistence farmers into producers is also about making them into (capitalist) consumers, and broadly capitalist subjects. 
can incite drastic impacts on nutrition in the distant producer communities producing a respective food. This article thus seeks to link literature on the rise of "nutritionism" [2] and "fashion foods" ${ }^{[3]}$ in the US with the rather meager literature on producer community nutrition and the effects of global food trade on producer health. While nutritional dimensions of the quinoa boom has received plentiful media attention ${ }^{[4,5]}{ }^{2}$, most of which promulgates a tale of producers selling their entire quinoa harvests and no longer being able to afford quinoa, this article tells a more complex story in which rural and urban communities experience the quinoa boom in radically different ways, and in which the nutritional impacts change over the course of the boom. It argues that changing relations to quinoa consumption, which simultaneously symbolizes "traditional" past while heralding an economically prosperous future for farmers and the nation of Peru, are the result of complex individual and family-level negotiations regarding ideas about bodily health, tradition, and modernity.

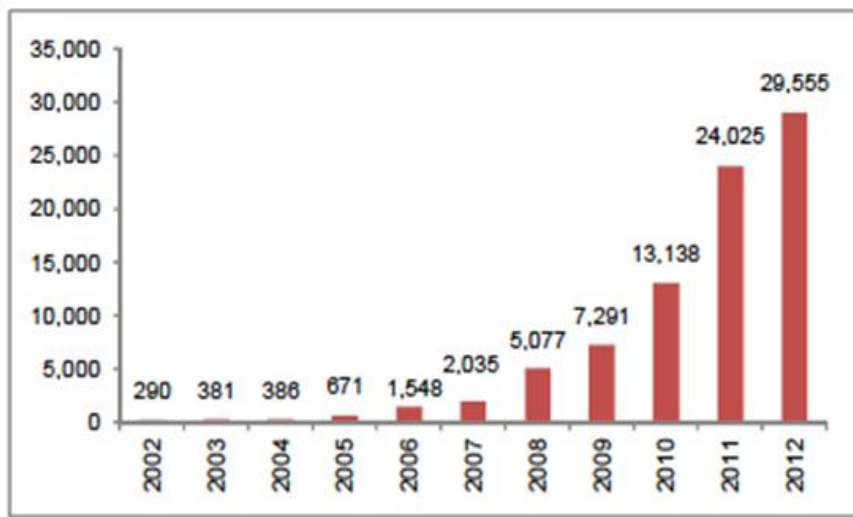

Figure 1: Peruvian Quinoa Exports 2002 - 2013 (in thousands of USD). Source: Peru Customs.

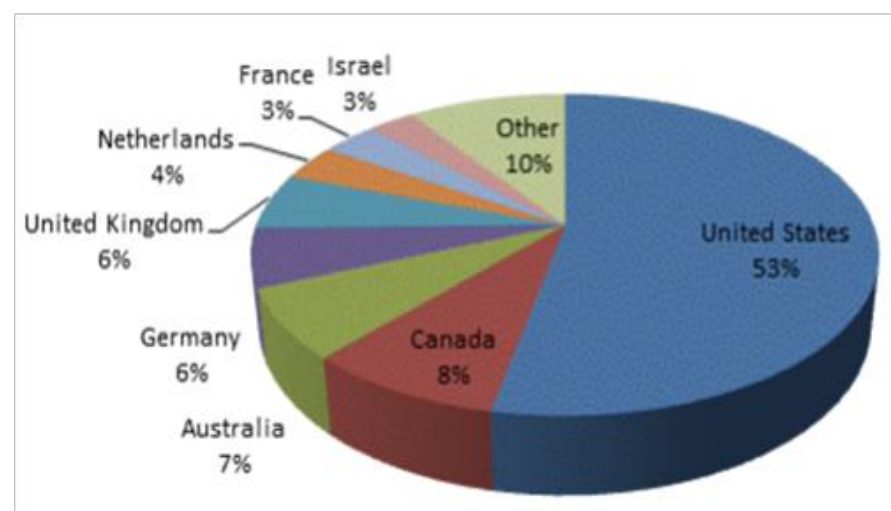

Figure 2: Peruvian Quinoa Exports, 2013.

Source: Ministry of Agriculture.

As commercializing traditional foods is increasingly endorsed as a tool to promote "multicultural" and "sustainable" rural development, it is critical that we understand the ways consumers come to desire traditional foods, and the temporal dynamics of such desires, as well as the implications of commercializing a traditional food for the nutrition of the commu-

\footnotetext{
${ }^{2}$ Catalyzed by the Guardian's 2013 article "Can vegans stomach the unpalatable truth about quinoa?" about a dozen major websites took up the "quinoa quandary" story between 2011 and 2013.
}

nities producing the food product. Two questions guide my inquiry ${ }^{[1]}$. What provoked the demand surge for quinoa in the US, and what anxieties and desires make quinoa a desirable food amongst consumers outside the Andes? ${ }^{[2]}$ What are the effects of the quinoa boom on producer community nutrition and urban populations in quinoa-producing nations? The article asks these questions in order to call attention to unintended consequences of commercializing traditional foods on producer communities, and to highlight the ways "health food" trends in the "Global North"3 impact distant producer communities. Broadly, it argues that anxieties about personal health and nutrition in the Global North, alongside anxieties about an industrial food system that incite desires for "traditional" cures, can lead to an extraction of nutrient-rich foods from the "Global South" in capitalist dynamics of extraction and appropriation. The article focuses on consumers in the US, the leading quinoa importer which accounts for over half of global quinoa imports (See Figure 2), and Peru, the world's leading quinoa producer and exporter.

This article draws up on pre-dissertation fieldwork conducted during summer 2014 and summer 2015, during the height of the boom and the beginning of the bust. The majority of this fieldwork was conducted in Puno, the hub of quinoa production in Peru where approximately $70 \%$ of the 2013 harvest came from. Fieldwork included interviews with quinoa farmers, quinoa buyers, development practitioners, agronomists, nutritionists, and policy-makers. It also included participant observation on quinoa farms and during quinoa buys. Data about quinoa consumption in urban areas comes from these interviews and also from informal conversations with urban Peruvians in markets and homes.

\section{Quinoa Nutritional Content and Agronomic Characteristics}

High in fiber (compared to other grains) an excellent source of protein, and rich in many vitamins and minerals, particularly calcium, phosphorus, and iron, quinoa's nutrient profile is nothing short of extraordinary ${ }^{[6,7]}$. Much of quinoa's nutritional acclaim in the US, however, derives from its protein content. While the amount of protein in quinoa is similar to that of wheat and other grains, quinoa's protein quality distinguishes it from other grains. The proteins in quinoa mainly belong to albumin and globulin, which have a balanced composition of essential amino acids much like milk's protein, casein $^{[8]}$. Likewise, quinoa is one of only a handful of plant-based foods considered a "complete protein," meaning it contains all nine essential amino acids that the human body does not make in roughly equal proportions. Many researchers argue that the consumption of quinoa has substituted for the lack of animal protein in the highlands, and in many areas, quinoa is still the principal protein source ${ }^{[9]}$.

Quinoa is also unique agronomically, which has contributed to its enduring centrality in highland food ways and also the emerging development discourse surrounding quinoa as a development solution. Thriving at extremely high altitudes (quinoa is commonly cultivated at 4,000 masl), in highly saline soils, and in drought conditions, quinoa thrives in the Andean Altiplano (high plain) where few other crops survive. With over two

${ }^{3}$ Realizing the problematic nature of categories of Global North/South and developed/underdeveloped, I put the terms in scare quotes. However, these categories are useful insofar as they highlight a pattern in where "traditional" foods come from (peripheries, being rural regions beyond cities and underdeveloped nations) and where they go to (industrial centers). 
hundred recognized varietals, quinoa's intra-specific diversity is exceptional, a trait that allows quinoa to survive in diverse climates, and be easily adapted to new regions or changing climactic conditions ${ }^{[10]}$. Quinoa's adaptability and resistance to harsh climates and environmental conditions make quinoa particularly important in the Andean highlands where harsh and fickle climates leave agriculturalists with few crop options.

\section{Pre-Boom Quinoa Consumption in Peru}

Domesticated around 5,000 years ago in the Andean highlands, quinoa has served as a culinary staple and cultural cornerstone for numerous Andean cultural groups ${ }^{[7]}$ (National Research Council 1989). The Inca spread quinoa production and consumption through much of South America during the Empire's colonization campaign in the $15^{\text {th }}$ century. In fact, quinoa production (prior to the recent expansion) maps roughly onto the contours of the Inca Empire ${ }^{[1]}$ (see Figure 3) (National Research Council 1989). Upon Spanish colonization, quinoa production and consumption (along with a host of other practices linked to native peoples' social and political life) came to be harshly stigmatized as a "comida de indios" (Indian food) ${ }^{[12]}$. The colonizers' project to eradicate quinoa was mostly unsuccessful. As Alexander von Humboldt observed during his $18^{\text {th }}$ century expeditions through the Andes, for inhabitants of the Andes highland peoples quinoa appeared to be akin to "wine to the Greeks, wheat to the Romans, and cotton to the Arabs" (National Research Council 1989). The Spaniard's denigration of quinoa as an "Indian food" engendered an enduring stigma that has long symbolically linked quinoa consumption to backwardness in the Andean regional imaginary.

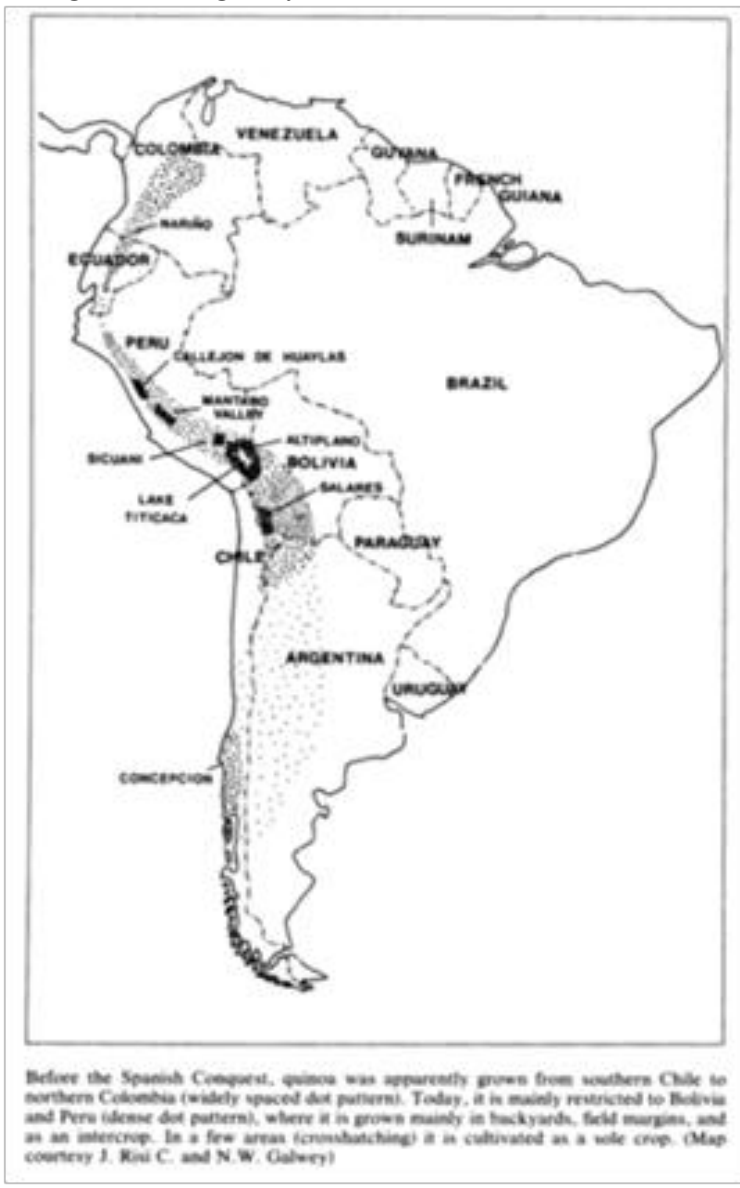

Figure 3: Quinoa Production Prior to Spanish Conquest. Source: National Research Council 1989.
For highland peoples, quinoa consumption is not only a traditional practice and expression of cultural identity, it is considered an important aspect of highly ritualized communion between people and land, or tirakuna (sometimes translated from Quechua as "earth beings"). $A s^{[13]}$ work on the use of coca leaves in the Andean cosmology shows, consumption of "local substances" (e.g. coca leaves, quinoa and other locally produced foods) are crucial practices in the Andean social world that establish and maintain "proper" relationships between humans and non-human beings. Likewise, decisions to consume or not consume quinoa (and take part in other practices falling in this category) are political decisions that identify one as part of the "runa" (person in Quechua, referring specifically to native peoples) social world or as "misti" (Quechua for Mestizo, and referring to the many others in opposition to runa). These oppositional identity categories, argues Allen, are enacted and negotiated through consumption practices and material engagements, such that to be misti is to not chew coca and to be Runa is to eat quinoa. Thus while quinoa consumption was (and is to a certain degree) disparaged and considered a marker of "Indianness," "backwardness," and poverty in the Andes, it was also a key practice for affirming group identity and solidarity while enacting relationships with non-human beings. Food is a foundation of collectivity, and consequently, of alterity ${ }^{[14]}$. Quinoa has long been denigrated precisely because the people who produce and consume quinoa are disparaged.

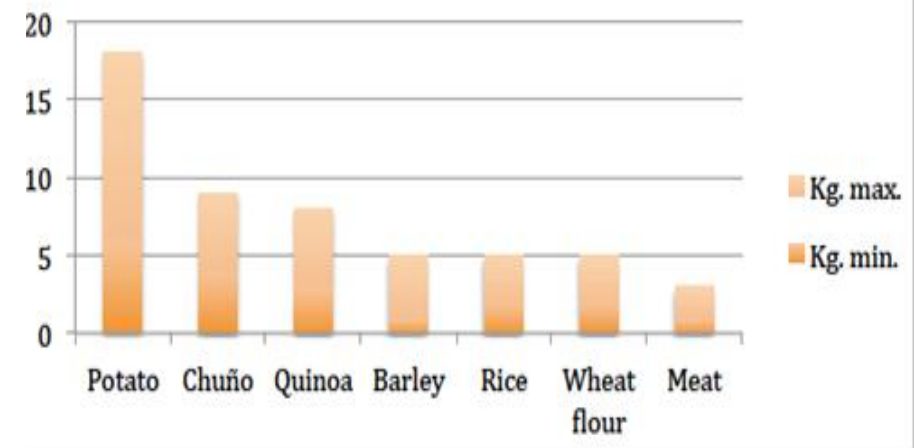

Figure 4: Average weekly food consumption by agriculturalists in Puno, 1977.

Source: (Egoávil, Reinoso, and Torres 1979) ${ }^{[15]}$

At the same time, quinoa consumption has been declining in the Peruvian highlands during the $20^{\text {th }}$ century, and people are rapidly replacing quinoa and other nutritious "traditional" foods with cheap imported foods such as rice and pasta in daily meals which as associated with "whiteness" and Western culture (though the degree of this decline in rural versus urban areas is not known ${ }^{[6]}$. Anthropologist discussion of the substitution of wheat bread for barley gruel in a highland Ecuadorean indigenous community provides a relevant corollary, as quinoa fits into a milieu of foods with similar symbolic associations of Indianness in the Andes including barley gruel. She argues that leavened white bread is symbolically associated with the dominant (i.e. "Westernized") culture, while barley gruel is associated with "tradition," a dynamic similar to noodles and rice alongside quinoa. Weismantel contends that while the substitution of one carbohydrate for another seems insignificant, as bread enters the indigenous kitchen as part of "a complex of cultural, ideological 
and social transformation, its significance can be greater than the effects on family nutrition or the household budget would seem to suggest" $(2000,136)$. Likewise, consumption decisions at the household level about what to eat and cook for one's family are highly politicized and inextricably linked to local ideas about progress and tradition, making the pressure to assimilate not a matter of abstract ideology but something that "pervades the textures of everyday life" $(2000,138)$. In the case of quinoa, the nutritional dimensions are indeed consequential as substituting a staple that is a rich source of proteins, vitamins, and nutrients for wheat noodles can have dramatic negative impacts on nutrient intake.

In rural highland communities dominated by subsistence agriculture, quinoa has remained a staple as harsh climates prevent farmers from adopting new crops (see Figure 4). However, massive rural-urban migrations in Peru during the last two decades have left an enormous urban poor population, most of whom are recent migrants living in extreme poverty. This population consumes less quinoa than their parents (most of whom were rural farmers) in an effort to acculturate and adapt to city life. This rejection of traditional foods cannot be read as a simple socio-economic problem (i.e. a result of poverty), but a complex shift linked to ideas about "progress" and "whiteness." However, as quinoa was very cheap prior to the quinoa export boom, for many urban migrants quinoa served as a buffer food that allowed them to maintain relatively high levels of nutrition even with meager incomes.

\section{The Boom}

Up until the 1980s, quinoa was mostly unknown by consumers outside the Andes, though a handful of agronomists had become familiar with the grain ${ }^{[16]}$. In 1983, two American entrepreneurs "discovered" quinoa while travelling in Bolivia and promptly formed the Quinoa Corporation, an export business shipping Bolivian Quinoa Real (a variety unique for its large, white seeds grown exclusively in the Uyuni Desert) to healthfood stores across the United States ${ }^{[17]}$. Quinoa demand outside the Andes increased incrementally through the 1980s and by 1988, 750 tons were sold in the US. As Bolivia's quinoa export market grew, and Peru's quinoa market remained domestic. In fact, Peru's National Food Program, PRONAA, was the largest buyer of Peruvian quinoa through the $1990 \mathrm{~s}^{[18]}$. Interestingly, the primary importer of Bolivian quinoa exports in the 1990s was Peru, much of which is trafficked illegally, making it unclear even today how much Peruvian quinoa is actually produced in Peru. International interest in the grain continued to increase slowly and by the late 1990s, US annual imports reached 900 tons ${ }^{[19]}$. Peru began exporting quinoa in 2002, though Bolivia still commanded $83 \%$ of worldwide quinoa exports. In the early 2000s, Peru's export capacity increased dramatically, increasing at an annual average of $47.8 \%$ between 2002 and 2013 (from 250 total tons in 2002 to 18,341 tons in 2013) and eventually surpassed quinoa as the world's primary quinoa producer and exporter $^{[20]}$.

By 2005, quinoa exports were booming. Demand had surged in the US, and was increasingly rapidly in Europe and Australia. The demand surge quinoa spurred a severe price hike, increasing export prices from 335 \$USD/ton in 2000 to 1,330 \$USD/ton in 2011 (approximately 400\%) ${ }^{[21]}$. Farmgate prices quadrupled between 2006 and 2012. In 2011, Peru's quinoa exports exceeded Bolivia's and between 2012 and 2013, Peru re- ported a 71\% increase in quinoa exports, totaling US\$ 78.3 million, compared to 2012. Peru now exports quinoa to 35 different markets (43\% to the US; $6.4 \%$ to Canada, $5.9 \%$ to Australia) ${ }^{[22,23]}$.

\section{Consumer Anxieties and the Desire for Quinoa in the US}

What led to quinoa's mushrooming popularity in the US (and increasingly Europe and Asia)? This article argues that consumer anxieties about personal health, alongside rises in gluten-free diets and veganism, alongside concern about the ill-effects of an industrial food system, created an opening for quinoa in US food scape. It also argues that quinoa's interpellation into a discourse of "super foods" led to quinoa demand surge. The article contends that the fickleness of these dietary trends, which the article argues follows a logic of fashion, highlights a major drawback in promoting "super food" production as rural development: namely it may only last along as a trend does.

The "gluten free" diet's popularity has exploded in the US in recent years. As of January 2013, 30 percent of U.S. adults reported reducing or eliminating gluten in their diets ${ }^{[24]}$, and only a small fraction of these people have celiac disease. Anthropologist ${ }^{[25]}$ examines the "contested illness experiences" of gluten-free dieters and finds that many gluten-free dieters question biomedicine's hegemony and reference an expanded of the list of ailments linked to gluten (as compared to the mainstream medical establishment's list of related ailments)and employ self-diagnosis and diagnosis of others. In other words, the gluten-free trend results in part from broader distrust of the medical establishment and dietary recommendations made by doctors and anxieties about personal health.

Entrepreneurs and marketing firms are capitalizing on this trend, and retail sales of gluten-free products increased almost 28 percent in the last 10 years to become a four billion dollar market ${ }^{[26,27]}$. As a gluten-free grain-like food, quinoa has become incredibly popular with gluten abstainers and avoiders. Not only is quinoa a popular as a wheat replacement in meals in its whole form, but many packaged baked goods (e.g. cookies, cakes) that normally contain wheat flour, now use quinoa flour as a wheat flour replacement.

Alongside the rise of the gluten-free trend, vegetarianism and conscious reduction of meat consumption has risen in the past decade. The just-released "Vegetarianism in America" study shows that 3.2 percent of U.S. adults, or 7.3 million people, follow a vegetarian-based diet. Approximately 0.5 percent, or 1 million, of those are vegans, who consume no animal products at all. In addition, 10 percent of U.S., adults, or 22.8 million people, say they largely follow a vegetarian-inclined diet (Vegetarianism in America Nationwide Survey 2008). A follow-up study in 2013 found that the total number of vegetarians had doubled to 5 percent ${ }^{[28]}$ (In U.S., 5\% Consider Themselves Vegetarians n.d.). Perhaps more importantly, is the rise of veganism. While vegetarians can eat animal protein in eggs and dairy, vegans can only get protein from plant sources, and thus quinoa's complete protein status is alluring.

A key worry for vegetarians and vegans in particular, especially those in the US where average protein intake is double the Dietary Reference Intake and many people believe vegetarians will inevitable suffer from protein deficiency ${ }^{[28]}$, is whether they are consuming adequate protein. As a rare plantbased "complete protein," quinoa is touted by vegetarian blogs and doctors alike as an ideal protein source for vegetarians. For 
vegans in particular, who cannot get "complete proteins" from eggs and other animal products, quinoa has increasingly become a staple food.

Alongside quinoa's attractiveness for gluten-free dieters, vegetarians, and vegans, quinoa was deemed in the popular press as a "super food." Headlines in mainstream newspapers as well countless blog entries and other websites discuss quinoa as a super food or "the Incan super food." The term super food, which was added to the Webster English Dictionary in 2014, has come to be used to discuss a numerous foods with dense nutrient content. While many nutritionists criticize the term as an advertising ploy, (in fact the UE banned the use of the term for this reason) nonetheless the term is clearly powerful for consumers. Articles claiming quinoa's super food status have been important in introducing quinoa to a broader consumer base, beyond vegetarians and gluten avoiders, as super food refers in a vague sense to quinoa nutritional "goodness." The superfood discourse is related to a broader category of "fashion foods," which are food that follow a logic of fashion. In other words, foods come into fashion in sudden trends, and also fall out of fashion when another food trend takes their place ${ }^{[3]}$ (Brondizio 2004). Fashion foods thus lead to boom-bust cycles in which foods are suddenly popular and then suddenly forgotten when a new food booms.

Thus quinoa is often read through a discourse of nutritionism ${ }^{[29,30]}$ in which quinoa's value is primarily an outcome of its nutrient components. Quinoa is important to gluten-free dieters due to its lack of gluten, to vegetarians and vegans because of its rich protein, and to others because of its general "superfood" nutrient density. Yet this article demonstrates that there is more going on here in terms of quinoa's allure to US consumers.

Alongside the rise of gluten-free, vegetarian, and vegan diets, quinoa's sudden attractiveness is also related to a broader disenchantment with the industrial food system that has fueled consumer trends such as organics, fair trade, and the Slow Food Movement $^{[31]}$ (Guthman 2003). Quinoa is marketed as a "traditional miracle food" and a "lost crop of the Inca" and packaging commonly features photos of decidedly "traditional" looking people or Inca figures and often include lengthy discussions of quinoa's role as the "Mother Grain" in the mystical Inca Empire. As a growing subset of consumers lament the industrialized food system, consumers increasingly find solace in traditional foods, evidenced by the surfeit of foods with packaging featuring images of rurality and "times past," the rise of rural tourism, and farmers markets ${ }^{[32,33]}$. The increasing popularity of foods explicitly marketed as traditional foods and contributed to the sudden demand surge for quinoa and is a pattern evidenced by the popularity of foods marketed as traditional such as chia seeds and also artisanal breads and cheeses.

In addition to fitting into this traditional foods category in the US consumer imaginary, quinoa is linked to another powerful symbolic figure, "the Indian."[34] argues, the figure of the Indian, as the specter of the "colonisable subject," maintains a powerful and complex position in the Western imaginary. The Indian is amongst a class of objects that inspire "hatred and fear, [they are] objects to be despised yet also of awe...evil and mystery stabilizing the ship and course of Western history" (1987, 9). The emphasis in marketing and popular press articles on quinoa's use by the Inca and by modern-day "Indians" draw upon this power exuded by the figure of the Indian to reinforce and bolster quinoa's nutritional power.

\section{Nutritional Impacts of the Quinoa Boom in Peru}

As consumer demand for quinoa skyrocketed, so did its price (see Figure 5). Between 2007 and 2012, farm-gate prices quadrupled, peaking in 2013 at approximately 10 soles/kilogram (US\$ 3.00). For farmers, this price increase was a godsend: most highland farmers had produced quinoa for home consumption or traded it in local ferias for a meager 2 soles/kilogram (about US\$ 0.75 ) in previous decades. But as farm-gate prices rose, so did consumer prices, making it difficult for many of the urban poor consuming quinoa to purchase it. In interviews with urbanites in Puno and Lima in 2013, many fondly recalled the days when they could purchase a kilogram of quinoa for 5 soles, as in the 2013 a kilogram of quinoa in the market cost around 23 soles. In 2013, quinoa's place in soups and as the main starch on plates was being supplanted by rice and cheap noodles.

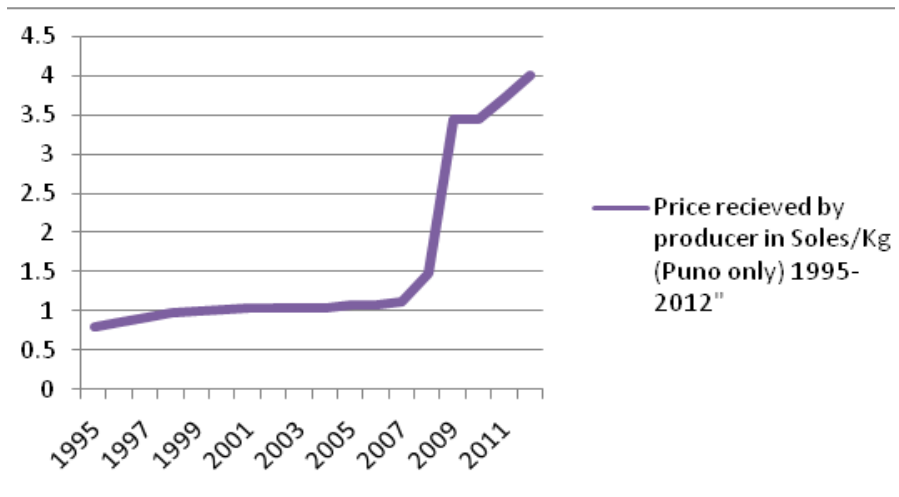

Figure 5: Price Received by Farmers in Puno (Soles/kg) 1995-2012. Source: InstitutoNacional de Estadística y Informática.

The impacts of the quinoa boom were decidedly different in urban and rural regions of Peru. In rural regions of the highlands, farmers who had long produced quinoa as part of a diverse portfolio of crops increased production of quinoa to take advantage of high price. Space that was previously dedicated to diverse potatoes or legumes was replaced by quinoa. None of the interviewed farmers sold all their quinoa: they all saved part of their harvest for home consumption. However, farmers commonly saved different varietals for home consumption than those that they sold. While exporters preferred the large-grain white quinoas, many farmers discussed different culinary uses for different quinoa varietals, (e.g. dark quinoas were best in soups) and likewise many farmers cultivated separate plots of diverse quinoas for home consumption.

While farmers continued to consume quinoa, the new income also gave them access to consumer goods and increased purchasing power. Many farmers purchased Coca Cola and Inka Cola in local stores, though the lack of consumer infrastructure in local stores meant that farmers had to travel meager too far actually gain access to an increasing array of consumer goods. This increased buying power is commonly touted as a benefit of quinoa commercialization (and all traditional food commercialization), as theoretically it offers farmers more "food security" in a market sense ${ }^{[35]}$. Yet whether increased income actually translates into better nutrition in the quinoa case seems unlikely given pre-boom diets were nutritionally dense and many of the products in local markets are sodas and candy (stores in rural areas of the highlands are very small and mostly have sodas, candies, cookies for food and focus on procurement of other goods such as batteries). 
Interviews during summer 2015 did not focus on changing consumption practices amongst quinoa farmers, but this issue will be explored during the next phase of this project, which includes twelve months of fieldwork during Academic Year 2016 - 17. However, it does seems likely that while the quinoa boom did not reduce quinoa consumption amongst farmers, it did introduce them to a number of new consumer goods that they previously could not afford. The incomes earned from quinoa production gave producers a newfound power to purchase foodstuffs from stores.

Peru's urban poor on the other hand were negatively affected by the quinoa boom. For people living in highland cities, where quinoa was commonly eaten, and in Lima's periphery, where quinoa served as a nutritional buffer in extreme poverty, the skyrocketing price of quinoa caused a radical decline in quinoa consumption. While no official statistics document the degree of this decline, in interviews and informal conversations with residents of Puno and Lima, many said that the high cost prevented them from buying quinoa. Many had replaced quinoa with cheap starch substitutes, primarily rice and wheat noodles. Nutritionally, this replacement is incredibly problematic as quinoa has much more nutritionally dense that rice or noodles, and many of those living in urban poverty did not have means to afford (or access to) fresh fruits and vegetables that could replace quinoa nutritionally. The vast majority of quinoa produced between 2007 and 2013 in Peru was destined for export.

The rising quinoa prices and corresponding reduction in access for urban poor caught the attention of policymakers and the international media, and was used to justify the expansion of quinoa production outside the Andes. Reports published by the FAO, media entities, Peru's Ministry of Agriculture argued that increasing quinoa supply would reduce prices and allow quinoa to be accessible to more people. The FAO deemed 2013 the "International Year of Quinoa" in an effort to expand quinoa production in the name of solving global hunger ${ }^{[36,37]}$. Quinoa production was initiated along Peru's coast (where yields are 2 - 3 times that in the highlands) and quinoa production has rapidly expanded in nations around the world, particularly the US, Canada, Italy ${ }^{[38]}$.

At the same time, quinoa was gaining acclaim in Peru's upper-class social worlds, and came to hold a key position in Peru's "Gastronomic Boom." While fine-dining restaurants in Lima had long been modeled on European cuisines, and ingredients and dishes from the Andes were considered street or peasant food, around 2000 a major effort to create a distinctive Peruvian cuisine, called Novo Andino (or new Andean) commenced. Novo Andino cuisine retooled indigenous dishes from the notorious cuy (guinea pig) to mashua roots and presented them as fine dining. Spearheaded by Peru's now famous celebrity chef, Gaston Acurio, Peruvian food quickly gained international acclaim such that now Peruvian restaurants are opening all over the world and some are ranked among the best restaurants in the world. With the rise of Novo Andino cuisine, Peru's upper classes have begun consuming "traditional" Andean foods and consumption of quinoa, long a denigrated Indian food, has come to be a status marker. Scholars have remarked on the phenomenon of the middle-class "indigenous mestizos" in Peru, who according to anthropologist ${ }^{[39]}$ are apt at appropriating symbols of indignity. It seems indigenous cuisine is now being appropriated by Peru's middle class as a signifier of wealth and class. Novo
Andion cuisine, as articulated by a curio, is explicitly promoted as a social justice project, a development program that brings the "cosmopolitan promise of integrating a fragmented nation and exporting Peruvian culture to the world" ${ }^{[40]}$. However, the quinoa boom's impacts on nutrition and agro biodiversity, along with its rather quick transition from a boom into bust, brings into question whether rural areas will see sustained benefits from the Novo Andion cuisine and whether it can deliver on these lofty goals.

The changing nutritional geography of Peru's quinoa boom rapidly shifted again when quinoa "busted" in 2014. As a result of the expansion of quinoa production into new regions and technological advances (e.g. "improved" seeds) that increased quinoa's agricultural productivity, the price of quinoa priced dropped dramatically in 2014. While many farmers had received 10 - 12 soles/kilogram for their 2013 harvest, the average farm-gate price in 2014 was 3 soles. Many farmers in Puno refused to sell their quinoa and accused buyers of cheating them. At the same time, large-scale industrial farmers along Peru's coast were ramping up production of high-yield quinoa's that required massive amounts of pesticides (as a result of displacing quinoa from its native highlands, they needed to apply pesticides as quinoa is susceptible to the low-altitude pests). While farmers were enraged by the price drop, people living in urban areas rejoiced as they once again could afford to buy quinoa. During my 2014 fieldwork, quinoa soups began appearing on menus in working class eateries, and people working outside the quinoa industry celebrated the price drop. Thus while the quinoa boom was a boon for farmers and a problem for urban poor, the bust was a problem for the farmers and something for urbanites to celebrate.

\section{Conclusion}

This paper has used the quinoa boom as a case study to examine the nutritional dimensions of traditional food commercialization, and specifically the consumer desires that make such foods attractive and the impact of traditional food commercialization on nutrition in producing nations. It has also sought to provide a model for studying consumer and producer communities together. While many studies examine consumer trends, most of these ignore the impacts on producer communities, and at the same time the studies examining agricultural producer nutrition rarely examine the relationships to consumers of the foods they produce. Quinoa rose to international fame due to its rich nutrition as well as its linkage with the Inca Empire. The rise of gluten avoiders, vegetarianism, veganism, and the discourse of "super foods" created an opening for quinoa in the US foods cape. The impacts of the quinoa boom on producer's communities and residents of producer community nations has been complex. While highland smallholders benefitted from the price surge, urban poor who had previously consumed quinoa were forced to replace quinoa with cheaper foods. However, the recent quinoa bust has reversed these dynamics such that few highland smallholders can make a living on quinoa while urban poor can once again consume this food that has long been central in daily diets. These trends are likely to be patterns in traditional food commercialization, and thus bring to the fore major challenges for traditional food commercialization that allows sustainable poverty alleviation for producers while not pre- 
venting other traditional consumers of the food from accessing it. As markets for traditional foods and "super foods" grow in first-world countries, it is imperative that we design institutions to address these problems and find balance between producer profits and access to the traditional food in domestic markets.

\section{References}

1. MINAGRI.. Quinoa: Production and Export Statistics. (2014)

2. Pollan, Michael. The Omnivore's Dilemma. (2007) New York: Penguin.

3. Brondizio, E.S. (2004). From Staple to Fashion Food: Shifting Cycles and Shifting Opportunities in the Development of the Acai Palm Fruit Economy in the Amazon Estuary.

4. Romero, Simon. Quinoa's Global Success Creates Quandary at Home. (2011) New York Times.

5. Blythman, Joanna. Can Vegans Stomach the Unpalatable Truth about Quinoa? (2013).

6. Weismantel, Mary J. The Children Cry for Bread: Hegemon and the Transformation of Consumption. (2000) Nutr Anthropology 105-124.

7. Repo-Carrasco, R., C. Espinoza., S. Jacobsen. Nutritional Value and Use of the Andean Crops Quinoa (Chenopodium Quinoa) and Kañiwa (Chenopodium Pallidicaule). (2003) Food Reviews International 19(12): $179-189$

8. Jacobsen, Sven-Erik. The Worldwide Potential for Quinoa (Chenopodium Quinoa Willd). (2003) Food Reviews Intern 19(1-2): 167-177. 9. Lost Crop of the Incas: Little-Known Plants of the Andes with Promise for Worldwide Cultivation. (1989) Washington, DC: (NRC).

10. Repo-Carrasco, R. Contents of Amino Acids in Some Andean Grains. (1991) Food Human Nutrition.

11. Tapia, M.E. Underexploited Andean Crops And Their Contribution to Food. Santiago, Chile: (1997) FAO.

12. Tapia, M.E. 2012. La Historia de La Quinua: Un Proceso de Miles de Años. Paper presented at the Grupo de Investigación e Innovación en Biocomercio: Año Internacional de la Quinua, 2013, Lima, Peru, February.

13. Planella, María Teresa, María Laura López, and María Christina Bruno. 2014. Domestication and Prehistoric Distribution. In The State of La Quinua in the World of 2013 Pp. 33-48. Santiago, Chile and Montpellier, France: FAO and CIRAD.

14. Allen, Catherine. The Hold Life Has. Coca and Cultural Identity in an Andean Community. (2002). Washington, DC: Smithsonian Inst Press.

15. Bessiere, Jacinthe. Local Development and Heritage: Traditional Food and Cuisine as Tourist Attractions in Rural Areas. (1998) Sociologia Ruralis 38(1): 21-34.

16. Egoávil, M., J. Reinoso, and H.A. Towers. 1979. Simon Bolivar Fund Project: Promotion of Agroindustrial Production of Quinoa in the Department of Puno; Analysis of the Costs and Channels of Marketing of La Quinua. Simon Bolivar Fund. Lima: National Technical University of the Altiplano.

17. Bazile, Didier., Flora, Baudron.. The Dynamics of the Global Expansion of Quinoa Growing in View of Its High Biodiversity. (2013)
Art Report on Quinoa around 42-55.

18. Thier, Dave. The Story of a Cursed Crop.(2010) The Atlantic.

19. Hellin, Jon, and Sophie Higman. 2003. Quinoa and Food Security. In Feeding the Market: South American Farmers, Trade and Globalization. Bloomfield, CT: Kumarian Press.

20. MINCETUR. 2013. Monthly Report on Exports. Commercial Statistics - Exports. Lima: Ministry of Foreign Trade and Tourism.

21. FAOSTAT. 2014. Quinoa Production in Peru 1961-2012. Rome, Italy: Food \& Agriculture Organization.

22. INEI. In The International Year of Quinoa. Lima: National Institute of Statistics and Informatics. (2014)

23. NPD Group.. Percentage of U.S. Adults Trying to Cut down or Avoid Gluten in Their Diets Reaches New High in 2013 Reports. NPD (2013) NPD Press Release.

24. Moore, Lauren Renée.. "But We're Not Hypochondriacs": The Changing Shape of Gluten-Free Dieting and the Contested Illness Experience. (2014) Soc Sci Med 105: 76-83.

25. In U.S., 5\% Consider Themselves Vegetarians. N.d. Gallup. (2015). 26. Sapone, Anna., Julio, C., Bai, Carolina, Ciacci, et al.. Spectrum of Gluten-Related Disorders: Consensus on New Nomenclature and Classification. (2012) BMC Medicine 10-13.

27. Dietary Reference Intakes for Protein. (2005) Washington DC: National Academies.

28. Scrinis, Gyorgy.. On the Ideology of Nutritionism. (2008) Gastronomica 8(1): 39-48.

29. Guthman, Julie.Fast Food/organic Food: Reflexive Tastes and the Making Of'yuppie Chow'. (2003) Social \& Cultural Geography 4(1): $45-58$.

30. Guthman, Julie. Agrarian Dreams: The Paradox of Organic Farming in California, (2004) 11:264.

31. Taussig, Michael, Shamanism, Colonialism, and the Wild Man: A Study in Terror and Healing. (1987) Chicago: Uni Chicago Press.

32. Bouis, Howarth E., Lawrence, James, Haddad. Effects of Agricultural Commercialization on Land Tenure, Household Resource Allocation, and Nutrition in the Philippines. (1990) Intl Food Policy Res Inst. 33. McDonell, Emma. Miracle Foods: Quinoa, Curative Metaphors, and the Depoliticization of Global Hunger Politics. (2015) Gastronomica 15(4): 70-85.

34. de, la, Cadena, Marisol. Indigenous Mestizos. (2000) Durham.

35. García, María, Elena. The Taste of Conquest: Colonialism, Cosmopolitics, and the Dark Side of Peru's Gastronomic Boom. (2013) J Latin American Caribbean Studies 18(3): 505-524.

36. Launch of the International Year of Quinoa. (2013) FAO.

37. Laguna, Pablo.. Feasability Study for Fair-Trade Labeling of Quinoa in Ecuador, Peru and Bolivia. (2003) German Technical Cooperation. 38. Packaged Facts Gluten-Free Foods and Beverages in the U.S. Marketing Report. (2012). Rockville, Maryland: Packaged Facts.

39. Setareh Kamali, Setareh.. Adults' Daily Protein Intake Much More than Recommended. (2010) NCHStats: A Blog for the National Center for Health Statistics.

40. Vegetarianism in America Nationwide Survey. 2008. Harris Interactive Service Bureau: Vegeterian Times.
Online ISSN: 2377-0619

Journal Title: International Journal Food and Nutritional Science Journal Short Name: Int J Food Nutr Sci
Ommega Online Publishers

E-mail: foodscience@ommegaonline.org

Website: www.ommegaonline.org 